\title{
Friedrich Nietzsche's Superman and Its Religious Implications
}

\author{
Anthony C. Ojimba (Ph.D) $)^{1^{*}} \quad$ Bruno Yammeluan Ikuli (Ph.D) $)^{2}$ \\ 1.Department of Philosophy, University of Nigeria, Nsukka, Enugu State, Nigeria \\ 2.Institute of Foundation Studies, Federal University, Otuoke, Bayalsa State, Nigeria
}

\begin{abstract}
This paper examines Nietzsche's idea of the superman and its religious implications, with a view to showing that despite Nietzsche's rejection of Christian religion and his attack on religious moral ideals, using his concept of the superman, Nietzsche fails in stripping humanity/man of his religious nature. Nietzsche's superman represents the highest principle of the development of humanity and the affirmation of man's full potentialities. He posits the superman as a critique on Christian religion and the crisis of modernity. This is because, according to him, the Christian morality stifles the development, freedom and creativity of humanity/man, as well as making him dependent on faith. Consequently, he advocates for the total rejection and abolition of the Christian moral ideals in order to make way for the freedom of humanity/man and consequently the emergence of super-humanity. Attempts are made to articulate Nietzsche's concept of the superman and to highlight its link with his entire philosophic system. This will be examined critically, in each segment of the paper, to show its implications for religion. The paper employs the method of historical hermeneutics and textual analysis/exposition.
\end{abstract}

Keywords: superman, religion, morality, reevaluation of values, Christianity, nihilism and modernity.

DOI: $10.7176 / \mathrm{JPCR} / 45-03$

Publication date:October $31^{\text {st }} 2019$

\section{Introduction}

Nietzsche's concept of the superman represents the highest principle of development of humanity. It designates the affirmation of man's full potentiality and creativity. It is the affirmation of one's fate whether pleasurable or painful. This means saying yes to life and not no to life's challenges. Nietzsche posits the concept of the superman as a critique on religion, morality, and the crisis of modernity, as well as a panacea to the social problems of his time. This was the period of enlightenment, which was characterized by the belief in progress, achieved through the application of reason, rejection of religious beliefs and traditional morality. During this period, morality and religion were subjected to serious critical examination. This resulted in the rejection of the application of faith with reference to matters of practical life.

Nietzsche's doctrine of the superman (Übermensch) was given a detailed treatment in his most favourite book: Thus Spoke Zarathustra. Through the prophet, Zarathustra, Nietzsche expounds his diagnosis of modernity and Christianity as decadence and nihilism. Zarathustra announced the "death of the modern man and the advent of a new man, superman, who has liberated himself from the tyranny of religion" (Nietzsche, 2010, p.75-80). Nietzsche opposed most of the commanding ideals of his own generation, especially, the notion of equality. The idea of the superman (Übermensch) has been considered by some interpreters as "an aristocratic attempt to revaluate modern politics" (Fortich, 2010, p.76). Certainly, Nietzsche did not consider his age one of automatic progress or inevitable enlightenment. On the contrary, he saw it as possibly "the final chapter in the dwarfing of man -the leveling and mediocritization of humans that have begun with Socrates and Christ" (Cited in Fortich, 2010, p.76). Against the ideal of Christian morality, equity and progress, Nietzsche pits the counter ideal of the superman. Admittedly, if the modern era, which he considers as decadent, has to be overcome, a revaluation of the Christian values is imperative for the superman. This is why he is of the view that "humanity is something that must be overcome" (Niezsche, 2006, p.5) to make way for the emergence of the higher man - the superman.

Nietzsche (2006) conceives the superman as "an expression of free-spiritedness, the essence of humanity, the affirmation of one's full potentialities, authority, power, freedom and creativity, as well as the highest principle or development of humanity" (Cited in Ojimba, 2014, p.14). Certainly, there are great thinkers, in the history of philosophy, who reflected on similar idea. In the Republic, Plato (1973) is of the view that the "philosopher king" represents the highest embodiment of potentialities, knowledge, creativity and the right "qualities to guard the state" (p.89). This conception of the "philosopher king" by Plato has the same connotation as that of Nietzsche's superman. However, Nietzsche does not tie his idea of the superman to any metaphysical principle, as Plato did, by identifying the "philosopher king" as the only "being," who can make use of dialectics to get to the metaphysical or the ideal world.

In the Civita Dei, Augustine (1958) postulated the idea of the prince, which has the same affinity as that of Nietzsche's superman. For him, the prince represents an expression of authority and power, who controls the affairs of his state. According to him, "the prince is the world's lord and a supreme leader, who exercises control over himself and his subjects" (Augustine, 1958, p.88). However, Augustine ties the Prince's authority to God, while Nietzsche's superman is not subordinated to anybody. Similarly, Machiavelli (1958), in The Prince, toed 
the same line of thought, as he identified the prince as "the highest ruler, who exercises absolute and tyrannical power over his subject" (p.17). The prince, as the highest authority and expression of power and creativity has similar connotation with that of Nietzsche's superman. However, while Machiavelli's prince, as the superman of the state, is restricted to politics, that of Nietzsche has a wider connotation, which can be applied politically, religiously, socially, psychologically and otherwise.

Locke (1986), in the Two Treaties on Government, identifies the "legislator as the highest expression of political authority in the state" (p.310) which positions the legislator as a political superman. This has an affinity with that of Nietzsche's superman. But while Locke's concept of the legislator, who is the superman, is restricted to political authority, that of Nietzsche has a wider applicability. In a similar vein, Rousseau (1968), in The Social Contract, followed Locke's line of thinking. For him, the king represents the highest expression of authority, knowledge, mastery and freedom, which is bestowed on him by "conventions" (Rousseau, 1968, p.77). The concept of kingship, as Rousseau conceives it, had a link with that of Nietzsche's superman. This is because, both exercise freedom and represent the highest expression of knowledge and authority. However, while Rousseau's idea of leadership, authority, freedom and power, are bestowed by convention, that of Nietzsche is not bestowed by anybody but oneself.

Cicero (1973), in the Republic, concentrates the highest authority, knowledge and creativity with the magistrate, whom he sees as the sovereign and authority in the state. The magistrate, as stated by Cicero, who exercises authority over himself and others, has the semblance of Nietzsche's superman. However, Cicero is of the view that the magistrate is, in the final analysis, controlled by God (religion), while Nietzsche's version of the superman is controlled by no being, including God. Rather, the superman, for Nietzsche (2006) is "a manGod: the highest expression of freedom from the tyranny of religion. This informs why he declares "the death of God" (Niezsche, 2001, p.106), which means "the collapse of the suprasensory world" (Heidegger, 1977, p.61) and upholds the "emergence of the superman" (Nietzsche, 2006, p.6). This is because Nietzsche is of the view that religion stifles the human freedom, creativity and potentialities of man and makes him dependent of faith, which he interprets as highly fictitious and deceptive. He accuses the Christian religion of working against the exercise of man's authority, insofar as it is dependent on faith. He also frowns at the European civilisation, which is based on faith and the Christian concept of God. He is critical of Christian religion and traditional morality, because, he believes that they stifle man's development. Furthermore, he is of the view that "Christian morality makes man appear weak and helpless in the face of life's challenges and gives him the hope of "a beyond, - the true world or the heavenly world - which has now been discovered to be a fiction" (Nietzsche, 2005, p.171). Consequently, he advocates for the abolition of the Christian religious moral ideals, to make way for the emergence of a higher humanity - the superman - and for the individual to exercise his creativity, freedom and authority in tackling his problems. But since man is a religious being, is it possible for him to survive without religion, as Nietzsche recommends? Secondly, since Nietzsche is critical of absolutes, is the superman not an imposition of another absolute?

Against the backdrop of Nietzsche's attack on religion, this paper argues that Nietzsche's rejection of the Christian religious moral ideal and his attempt to stripe man of his religious nature, using his concept of the superman, is impossible because man is a religious being and cannot do without religion. It further argues the Nietzsche's superman ends up being an ideal postulation, which is not existentially tenable. To accomplish its major aim, the paper is divided into eight sections. In section one, Nietzsche's concept of the superman is articulated. Section two takes a look at the relationship between man and the superman. Section three examines the superman as an expression of free spiritedness. Section four is an attempt to relate the concept of the superman to religion. Section five looks at morality and the superman, while section six looks at the relationship between Nietzsche's declaration of the death of God and its connection with the superman. Section seven examines the superman and trans-valuation of values, while section eight evaluates the link between the superman and the Will to Power. In section nine, an attempt is made to evaluate Nietzsche's concept of the superman and to show that Nietzsche was unsuccessful in striping man of his religious nature using his concept of the superman. This section also serves as the conclusion.

\section{The Concept of the Superman}

Nietzsche's concept of the superman is fully discussed in his most favorite book: Thus Spoke Zarathustra, which he describes as "a book for all and none (Nietzsche, 2005, p.iii)." The superman is the theme of the first speech in Zarathustra's prologue, which he presents to the crowd, who gathered to hear him. The theory of the superman would be a myth, which possesses truth, in so far as it enables the higher type of man to develop his full potentials (Coplestone, 1963, p.32). It is the affirmation of life - saying yes to life, and not no to life's challenges. The superman represents the affirmation of one's full potentialities, freedom and creativity. It designates the essence of humanity; that is, the highest principle or development of humanity. It is a statement of freedom and liberation of man from the tyranny of Christian religion and moral absolutism. It is important to note that Nietzsche's superman is an ideal postulation and not a personality that would result from the practical 
application of his philosophy to life.

Nietzsche's superman does not negate life but affirms it. It represents the capability to transform the world and uphold one's freedom, potentiality and creativity. However, the superman can only accomplish this through the forceful rejection of existing moral and religious principles, which, to a large extent, have been neglected by modern culture. In Nietzsche's view, Christianity had concentrated attention on God-man, but since 'God is dead,' it has to be replaced by the man-god. This new man-god is "the superman - the noble man, who combines the beauty and strength of the animal with intellectual powers, which will enable him to conquer himself, the masses, the world and even fate" (Roubiczek 1966, p.32). The superman is "the master of the earth," (Nietzsche, 2005 , p.6), fulfilling the mission of the earth and giving meaning to history. In other words, he is a law giver, a law interpreter and one who directs the affairs of the earth - a man-god.

The superman is also an embodiment of life-affirmation through the acceptance of the totality of life and the suffering entailed in living. Nietzsche posits the superman as a being, whose distance from conventional humanity is greater than the distance between man and beast. Thus, "the superman rejects all conventional human practices and values and invents his own value, which in relation to the existing values, will be new ones" (Nietzsche, 1966, p.135). He represents the essence of humanity - one who breaks the tradition of metaphysical and religious absolutism.

It is a commonplace that every religion points to an ideal man in which its ideals are symbolized. The image and personality of such a person serve as a centre point and a way of life for those willing to follow it. Christ and Buddha are examples of such symbols. Christianity embodies its ideas in the personality and image of Christ. In his gospel of the new religion, Nietzsche tries to set up such an ideal on a big scale and this is embodied in the image of the superman.

According to Nietzsche (1966), "the Christian morality," which he calls the herd morality" (Nietzsche, 1966, p205), had confused the modern man, who has disguised himself in morality. It was his conviction that the Christian morality and religion have enfeebled man, striping him of his freedom, potentialities and creativity and, thereby, making it difficult for the emergence of a higher humanity - the superman. Nietzsche is of the view that the superman is the highest development of humanity and that man is only a bridge to the superman.

\section{Man and the Superman}

What is great in man is that he is a bridge and not an end. Man is a rope, tied between beast and overman (superman) - a rope over an abyss. Man shall be just that for the overman: a laughing stock or a painful embarrassment. Therefore, do not spend any time or energy on man! Mankind is not our goal, but the superman (Nietzsche, 2005, p.7).

It was Nietzsche's conviction that man had some developmental potential. This quickly brings to mind, the Darwinian concept of evolution. Man is still unexhausted for the greatest possibilities. Nietzsche states in Thus Spoke Zarathustra that man is, in his present state, weighed down by his bad conscience, is truly a sick animal, but, perhaps, this condition is like a pregnancy, a sickness heavy with the future possibilities. Thus, "man is such an incomplete, transitional creature that it almost seems as if nature had some future plans for him - as if man were not an end, but only a way, an episode, abridge, a great promise" (Fortich, 2010, 77).

In Nietzsche's (2005) estimation, "man is something that nature intended to overcome" (Nietzsche, 2005, p.5). This informs the reason why Zarathustra asks his audience what they have done to overcome man. This is, because, the people, who were listening to Zarathustra lived in a culture that eulogized equality, democracy, socialism and feminism, but Nietzsche was of the view that "these would not encourage the emergence of the superman, but the last man, which is man at the end of his developmental tether" (Cited in Fortich, 2010, 77.).

Nietzsche's superman is that being, which has overcome what has so far defined us as human - the now crumbling system of value. Since Nietzsche (2005) believes that "humanity is something that must be overcome" (p.5), the superman, thus, represents "the lightning, out of the dark cloud of man, the new ideal at which to aim" (Strangroom, 2006, p.18-9). He labels as 'human, all too human' the religious or transcendental hopes and illusions characterized by our current dying scheme of value: the believe that virtue consists in obeying the will of a dead God, that the fictitious rewards of the next life somehow excuse subjugation in this one and so on. Thus, the superman renounces all these, carving out his place in the world and according to his own will.

Nietzsche writes that "man is not the apogee of evolution, but a missing link to a higher species - the superman" (Nietzsche, 2005, p.7). These Supermen were not necessarily physically strong as the common interpretation of a superman implies. Although "they may be weak in one sense, they are creative in ways that allow them to move humans forward socially, economically, and in other ways" (Gayon, 2005, p.205). This implies that the superman is an embodiment of creativity, ingenuity and, in fact, an expression of free spiritedness.

\section{The Superman as an Expression of Free Spiritedness}

The highest man would have the greatest multiplicity of drives, in the relatively greatest 
strength that can be endured. He will obviously frighten religious people, because religion always seeks the extirpation of the drives (Fortich, 2010, p.78).

The superman is not necessarily a perfect physical specimen, a strong, healthy, athletic man, but an expression of free spiritedness. A sublime man could have the highest value, even if he is terribly delicate and fragile, because, an abundance of great and rare things have been bred and preserved together in him. When Nietzsche speaks of a 'higher type' that will become the 'higher aristocracy of the future', he is talking about the superman. This is the same group that is depicted as "the future masters of the earth, the legislators of the future, the free spirits of the future, the coming master race, the coming ruling caste- all of which must mean the same as his higher sovereign species, his stronger race, or stronger type" (Fortich, 2010, p.78). Thus, the superman represents an expression of a strong will and free spiritedness - an affirmation of one's full potentialities, freedom, creativity, natural drives, strength of the spirit and energy. It is a man, who has a strong will to liberate himself from the dictatorship of religion, which in Nietzsche's estimation, has enfeebled man, denied his freedom and creativity and made him incapable of facing life's challenges. This enfeeblement of man by religion, according to Nietzsche, informs why he declares the death of God and why he is critical of religion.

\section{The Superman and Religion}

The superman is precisely the one who knows that God is dead and that religion no longer control us. He knows that his kind needs no God for meaning; that one can comfortably live in a meaningless universe because one organizes a portion of it for oneself (Fortich, 2010, p.76).

Nietzsche's critique of Religion constitutes the main subject of the "First Book" of his "Revaluation of All Values," The Antichrist. His focus, here, is the Judeo-Christian religion. He repeatedly recurs to the idea that, even though "God is dead," "the Christian-nihilistic value standard still has to be pulled up and fought under every mask" (Nietzsche, 1967, p.32) According to him, "the Christian ideal" needs to be accorded a profoundly negative significance, because it involves the "attempt to make the virtues through which happiness is possible for the lowliest into the standard ideal of all values" (Nietzsche, 1967, p.111) Nietzsche's concern here has to do with positing these values as the highest principles and standard ideal by which all must live. This is, because, for Nietzsche, this makes it difficult and almost impossible for the development of a higher humanity, thereby, stifling man's freedom, creativity, originality and potentialities. This is a development Nietzsche considers to be detrimental to the enhancement of human life, and even to its general prospects for preservation in the long run.

Nietzsche favours individualism and rejects religious monotheism. This informs why he argues that with the modern collapse of Christian monotheism, the way has been opened up for a reconsideration of superior men. He notes that "without Christian theism as a buttress, the modern doctrine of equality appears to be a great impertinence" (Nietzsche, 2004, p.144) Similarly, in Thus Spoke Zarathustra, Nietzsche (2005) was of the view that "we used to be equal before God, but went ahead to say that since God has died and become unbelievable, belief in equality has become equally impossible for a rational person" (Nietzsche, 2005, p.232). Thus, for him, it is the time for us to reaffirm the order of ranks to intensify the pathos of distance that creates the psychology of the superior man.

Nietzsche (2004) views what has been revered as God, not as "godlike, but as miserable, absurd, harmful and as a crime against life" (Nietzsche, 2004, p.47). "I condemn Christianity," he writes, "because the Christian church has turned every value into an un-value, with its subterranean conspiracy against health, beauty, whatever has turned out well, courage, spirit, graciousness of the soul, against life itself" (Nietzsche, 2004, p.173-4) He further states that Christianity has made an ideal of whatever contradicts the instinct of the strong life to preserve itself and in various ways, hobbles and subverts those instincts, which aim at the preservation of life and at the enhancement of its value. Here, Nietzsche claims that value judgments have been stood on their heads, and whatever is most harmful to life is called good; whatever elevates it, enhances, affirms, justifies, and makes it triumphant, is called evil. Thus, for Nietzsche, the superman represents the liberation of man from the tyranny of the Christian religion.

The superman, in Nietzsche's view, designates a new way of thinking beyond the dichotomy of good and evil, which forms the foundation of the religious moral ideals - the Judeo-Christian interpretation of reality. For him, the superman, as a psychological and mental liberation of humanity from the moral and religious bondage of Christianity, provides a sense of direction for the already confused modern man, whose values have been basterdized by the Christian religion. He creates his own value, different from the existing Christian moral values and gives meaning to existence. He institutes a re-interpretation or reevaluation of the existing old values and assesses these values in accordance with how they enhance his Will to Power - in line with how they promote and enhance life, against the Christian moral ideals that despise life and this world. Thus, for Nietzsche, the superman represents the rejection and abolition of religious moral principles and the affirmation of this world and life, to the utter exclusion of the "other-worldly" - the heavenly world - which the Judeo-Christian morality preaches. It is the total liberation of the mind from the bondage of religion and morality. This informs the reason why Nietzsche extends his attack on religion to morality 


\section{On Morality and the Superman}

Nietzsche's critique on morality has to do with moral absolutism or morality as the highest principle (Oluwagbemi-Jacob and Ojimba, 2018, p.77). This, for Nietzsche, manifest chiefly in Christian morality. In his estimation, the Christian morality manifests itself in getting everybody to comply with certain principles and standards as well erecting certain ideals for the society. These principles by which all must comply are presented as originating from a supernatural source. For Nietzsche, this does not allow for man's freedom, creativity and full development of man's potentials. In his view, it does not allow for the emergence of a higher humanity, which symbolizes life's affirmation and full development of man. This is, because, moral absolutism, for Nietzsche, collapses the individual into the crowd and makes him too weak to rationally tackle his problem and face the challenges of life. Nietzsche contends that it makes man flee in the face of suffering and makes him helpless in the face of danger. This informed why he calls for the abolition of moral absolutes. For him, moral judgment is an illusion and there are, altogether, no moral facts. Put differently, he takes as his chief proposition that "there are no moral phenomena, but rather, only a moral interpretation of certain phenomena" (Nietzsche, 1967, p.149) Thus, for Nietzsche, morality is a question of interpretation and not an absolute principle or originating from a supernatural source. Thus, for Nietzsche, the superman offers a rescue mission from the absolutism of Christian morality. He represents a new way of thinking beyond the dichotomy of 'good and the evil' - the standard way of behavior set by this morality. This also designates independence and freedom from the moral and religious world order as the superman liberates himself from the tyranny of moral absolutism and from the religious interpretation of reality.

Nietzsche's superman creates his own morality - the master morality of strength and power - different from the Christian morality of the crowd. Admittedly, this brings to mind Heidegger's concepts of "authenticity" and "inauthenticity." The inauthentic living shows "Dasein" (man) as a being with others - the Das Man or the public person - while the authentic living represents him as an independent being (Cited in Ojimba, 2017, p.304). Similarly, Nietzsche's concept of the superman, which favours the master morality, designates a breakage freedom and independence from the absolutism of the Christian morality: the morality of the crowd. For him, the superman shows this morality not as "morality in itself," as the Judeo-Christian interpretation would show it, but as creations of the human mind. It portrays it not as originating from a supernatural source, but as expressive and interpretive phenomenon - the constructs of the Christian religion. Thus, the superman affirms the death of the moral absolutes - the collapse of the suprasensory world. This is why Nietzsche contends that the whole of European moral and religious values must now collapse, with the recognition that the belief in the Christian God, on which these values are hinged upon, is "unbelievable" and needs to be abolished. This informed why he declares the death of God, which represents, for him, a statement of crisis of value.

\section{On the Death of God, Nihilism, and the Superman}

Before, God! But now, this God has died. You higher men, this God was your greatest danger. It is only since he lies in his tomb that you have been resurrected. Only now the great noon comes; only now the higher man becomes - ruler. You higher men! Only now is the mountain of man's future in labour. God died: now we want the overman to live (Nietzsche, 2005, p.323).

The death of God, in Nietzsche's thinking, represents the crisis of value (Ojimba, 2017, p. 27). "God," in Nietzsche's thinking, represents the suprasensory world in general. God is the name for the realm of ideas and ideals. The pronouncement: "God is dead," means that "the suprasensory world is without effective power" (Heidegger, 1977, p.61).

Nietzsche believes that the suprasensory world, which represents the Christian interpretation of reality, from which God formerly exercised influence and power over its adherents, has prevented man from exercising and developing his potentialities, creativity and power. In his estimation, this has enfeebled man and stifled his freedom and ingenuity. In other words, it was Nietzsche's view that the suprasensory world has given man a false hope, which never existed. This informed why Nietzsche (2005) calls for the "abolition this suprasensory world" (p.32). The superman, as the highest development of humanity and the affirmation of man's freedom, creativity and potentials, thus, represents a critique on the suprasensory world, which is the meaning of Nietzsche's pronouncement of the death of God. The collapse of this suprasensory world marks what Nietzsche captioned nihilism, which indicates a state of crisis of value - a hopeless, valueless and a meaningless situation, in which the modern man found himself as a result of the death of God. The superman, for Nietzsche, represents the liberation of humanity from this value-crisis situation and who will rescue man from this state of passivity and decadence of value into the situation of activity and creativity. He frees man from this passive nihilism into a creation of new values.

Heidegger defines nihilism as "a historical movement, and not just any view or doctrine advocated by someone or other"(Heidegger, 1977, p.62.). Similarly, in the Will To Power, Nietzsche (Nietzsche, 1967) defines nihilism as "the devaluing of the highest value" (p.9) Nietzsche's understanding of nihilism, as the devaluation 
of the highest value, is a statement of crisis of value as hinted above. It is in line with this crisis of value that Nietzsche calls for the emergence of a higher humanity -the superman - who will lead man out of this crisis of value, which the Christian religion has landed him in, give meaning to this state of meaninglessness, value to this state of valuelessness, as well as provide a sense of direction for humanity. The superman represents the highest affirmation of this world and life as well as the highest level of development of man's potentials, creativity, ingenuity and freedom. The superman is the essence of humanity. What this implies is that Nietzsche posits the superman as a critique of the Christian morality and ideals, which in his view, stifle man's freedom by giving him a false hope of a 'beyond,' as well as making him appear weak and helpless in the face of danger and life's challenges. It is in line with the crisis of value, ushered in by the death of God that Nietzsche calls for a transvaluation of values.

\section{On the Superman and Transvaluation of Value}

Transvaluation of value represents Nietzsche's position on Christian morality. The superman is a key concept in Nietzsche's transvaluation of value. For him, it represents a new way of thinking beyond the dichotomy of 'good and evil' - a liberation from the control of Christian religion. Nietzsche's concern toward a revaluation of values was to work out a new theory of value, which would at once provide an interpretation and decisive reassessment of existing Christian moral and evaluative schemes, and also fill the normative void which their mere "devaluation" under critical scrutiny would otherwise leave. He insists that his critique of Christian morality and his revaluation of values are mandated by "intellectual integrity" and "honesty" in philosophical thinking. Thus, his reevaluation of values represents a critique of former values instituted by Christian and traditional modes of valuation as well as a development of a substantive alternative to them.

A clearer restatement of his program of a "revaluation of values" would be a revaluation of those things, which traditionally or commonly, are supposed to be of greatest value. In proposing such a "revaluation," Nietzsche (1989) takes himself to be expressing a new demand: "that we cease to take received estimations of these things for granted, and that the value of these values themselves must be called into question" (p.20). Nietzsche's concern here has to do with revealing the historical origin of these values as creations of human mind and not as originating from the first conditions of our existence or expressing an absolute principle or eternally fixed and unchangeable ideals as Christian interpretation of reality would have it. His reevaluation of values, thus, represents a dethronement of Christian moral values and ideals from their theo-centric preeminence assigned to them in the Judeo-Christian interpretation of the world. For Nietzsche, it is the superman, who initiates the dethronement of these Christian moral values and institutes the creation of new values.

The real worth of the new values, created by the superman, will be assessed in accordance with their value "for life" as Nietzsche (1967) conceives life as "will to power" (148). The superman, who recognizes himself as the "will to power" transvalues. He is the noble man, who adopts a value-creating relation to existence. For him, the superman creates his own value and gives meaning to existence. He assigns meaning to things as well as determining the worth of existence. In fact, for Nietzsche, he is the master of the earth. Just like in Dionysian relation to existence, the superman creates and destroys the world. For him, the superman represents the symbol of creativity, ingenuity, potentialities and freedom. The superman, through the transvaluation of values, symbolizes liberation from the Christian ideals and traditional morality, which in Nietzsche's estimation, stifle man's creativity and freedom. Nietzsche's transvaluation of value is, thus, a critique of Christian religious and traditional moral values. The superman, who initiates this transvaluation, recognizes himself as "will to power" and this makes the will to power a key concept in Nietzsche's philosophy.

\section{On The Will to Power and the Superman}

All beings seek to discharge their power and to dominate. The will of power always encounters and seeks to overcome resistance. The superman is self-domination and domination of others (Fortich, 2010, p.75).

Nietzsche (1967) understands life in terms of the desire to preserve and enhance power. This informs the reason why he defines life as "will to power" (Niezsche, 1967, p.148). The drive for enhanced power is the basic drive in man. Thus, the will to power is the essence of life. For Judeo-Christian values, such as humility and love, Nietzsche substitutes an ethics of power - the principle that might makes right. This is the logical consequences of Darwin's statement of the survival of the fittest, because, the best fitted individuals desire not merely to survive, but to acquire power over others (Sahakian, 1996, p.230). Instead of accepting the social instinct as a guide to conduct, Nietzsche advocates egoism and rugged individualism - the competitive striving to fulfill all egoistic instincts and accomplish personal advancement.

Nietzsche believes that European morality denies the central role of the "will to power" - and does so in a dishonest manner. He puts the blame for this upon the morality of Christianity. He was appalled that Europe should be subjected to the morality of the small group, who clustered around Jesus. He considers this as the most repugnant kind of degeneracy that civilization has ever brought into existence. In Nietzsche's estimation, 
Christianity denies the natural origin of morality, since it requires us to love God before we can love anything. It was Nietzsche's view that by injecting God into our affections, we subvert the immediate and natural standard that involves affirming life. By diverting our thinking towards God, for him, we dilute our strongest and most vital energy - "the will to power," which, alone, constitutes the essence of life.

Nietzsche posits the superman as an embodiment of the "will to power." He postulates the concept of the superman as a solution to the problem of cultural decadence and the enfeeblement of man by religion. He spoke of rising 'beyond good and evil,' by which he meant rising above the dominant Christian morality of his day. He envisioned a new day, when the truly complete person would achieve new level of creativity and thereby become a higher type of person - the superman, who is strong-willed enough to reject the Christian morality and invent his own morality - the master morality, which is an expression of the "will to power." This is, because, in Nietzsche's view, only the morality, based on the will to power, is an honest version of what the Christian morality has carefully disguised. Nietzsche is of the view that if the superman is cruel, we must recognize that almost everything we call higher culture is simply a spiritualized intensification of cruelty (Stumpf, 1996, p.385). Thus, from the perspective of master morality - the superman's morality - the word 'cruelty' simply refers to the basic "will to power," which is a natural expression of strength. Nietzsche's notion of the "will to power," therefore, is clearly manifested in the attitude and behaviour of the superman, who dethrones the Christian morality from its theo-centric pre-eminent position, assigned to it by the Judeo-Christian interpretation of reality.

Nietzsche posits that God is dead and that religion is invalid. He is of the view that if human life is to have any value or meaning, then, it is the superman, who will redeem mankind's existence. That is why Zarathustra exclaimed: "behold, I teach you the overman (superman). The overman is the meaning of the earth" (Niezsche, 2006, p.6). "Let your will say: the overman shall be the meaning of the earth!" (Niezsche, 2006, p.6). Thus, Nietzsche's superman is the highest affirmation of the "will to power:" an affirmation of one's full potentialities, creativity, power, and freedom from the tyranny of religion. It represents the affirmation of this world and life, to the utter exclusion of the other-wordly, which religion preaches and which, for Nietzsche, has enfeebled man and given him a false hope of a beyond (Ojimba, 2017, p.34). Therefore, Nietzsche's superman, who recognizes himself as an expression of the "will to power," is a direct critique on the Christian religion and morality. But the question is: did Nietzsche succeed in his quest to replace Christian religion with his gospel of the superman? This is the question, which the following section tackles.

\section{On the Critique of Nietzsche's Superman}

The doctrine of the superman represents an attempt by Nietzsche to deal with the problem of moral and religious decadence. Nietzsche wanted to evolve a system that would transform the moral and religious crises of his time. It was his conviction that the virtues of honesty, patience, kindness and love, preached by Christian morality, have enfeebled man and made him helpless in the face of life's challenges. In Nietzsche's estimation, this has denied man of his freedom and made him less creative. It does not allow for the expression of man's full natural power and energy, which constitute the basic drive in life. It was Nietzsche's expectation that the church would approve the concept of the survival of the fittest, similar to the doctrine of Thomas Hobbes' state of nature, which allows for the expression of the aggressive instincts, as well as the brute and animalistic tendencies in man. Zarathustra's doctrine of the superman, as a panacea to the axiological crisis of his time, was just a prophetic announcement. Thus, Nietzsche is concerned with the problem of crisis of value and this gives rise to his postulation of the concept of the superman as a solution to this problem.

Nietzsche describes the Christian morality as herd morality. He presents its adherents as weak, sick, weaklings and less creative. It was his conviction that they despise the body and the earth and have replaced them with their invention of the "heavenly world," which, for him, is a fictitious world (Niezsche, 2005, p.171). Consequently, he devises his own rigorous system for raising a society that will not depend on Christianity, because, he believes that Christian religion stifles man's creativity, freedom and potentialities. However, what Nietzsche fails to understand is that he cannot eliminate religion, because, man is a religious animal. This is, because, man's identity cannot be separated from his religion. Precisely, the elimination of man's religion would amount to elimination of his identity. This is, because, religion is a crucial factor in man's identity formation. It is closely linked to an essential part of the socio-historical matrix that provides the needed platform for identity formation (Erikson, 2013, p.11). It provides both a transcendental viewpoint that helps to forge moral beliefs and behavioural modus operandi based on ideological platform. Religious norms play an important role in transition of religious beliefs to a community of believers. This implies that religious beliefs, values and morals, help to empower man to better understand the world and his unique place in it. Ideologies generated through religion help to deepen one's understanding of events and experiences as well as associating meanings to these events and experiences.

The important role of religion is further emphasized in the part it plays in identity formation in a culture confronted with a continually fluctuating social and political milieu. Essentially, the transcendent meaning derived from religious affiliation is important for identity development and well-being. In the absence of the 
viewpoint available through religious beliefs, the worldview it provides, and its role in shaping and guiding behaviour, the multiplicity of choices and options accessible to the modern man is more likely to breed despair, hopelessness and confusion. This is, because, religion can provide ultimate answers and viewpoints about elusive issues of life that might be more intriguing and pertinent (Erikson, 2013, p.14). For instance, religiosity is found to be relevant in explaining commitment and purposefulness in terms of identity formation. This suggests that identity achievement is highly related with internalization of religious commitment. Besides, there is evidence suggesting that religious attendance is related to identity commitment choices of foreclosure and achievement, whilst, identity diffusion is associated with lower rates of religious attendance. Thus, religion is a key determinant of man's identity formation and man cannot live comfortably without religion. Consequently, Nietzsche's attempt to stripe man of his religiosity is an attempt to deny him of his identity, which is an attempt in futility, because, man is a religious animal and cannot live without religion.

Nietzsche was critical of Christianity, because, he believes that it stifles man's freedom and makes him dependent on faith. He, therefore, posits the superman as a concept of liberation from the tyranny of Christian religion and as an affirmation of man's freedom. But despite his stress on freedom, Nietzsche's philosophy was, in fact, a very suppressive inhuman ideology that aimed at enslaving others. The practical application of his philosophy to life would not only result in the survival of the fittest and the manifestation of animalistic and brute tendencies in man, but would also result in actual monstrosity. He rejected the notion of human equality and any form of fixed truth, morality or standard of behaviour; but this undermines our very notion of human rights, which presupposes a fixed and acceptable standard of behaviour. He despises weakness, compassion, and humanitarianism, preferring strength and domination. But this will only take man back to the state of nature, where there is man's inhumanity against man.

Nietzsche attacks Christian morality, because, it posits itself as the highest value and as the absolute principle. He, therefore, posits the superman as a creator of his own value and as a critique of this absolute morality imposed by the Christian religion. But the superman ended up being another absolute. This is, because, the superman is not just the personality that would emerge from the practical application of Nietzsche's philosophy to life, but the essence of humanity - the highest principle of development of man. It is an ideal principle, just like the Plato's "philosopher king," which amounts to an imposition of another absolute. Furthermore, Nietzsche's will to power, which, according to him, constitutes the essence of life and the most intimate essence of being, is an appeal to another absolute. Thus, Nietzsche accepted from the backdoor, what he rejected at the front door. He was critical of absolutes but ended up introducing another absolute - the superman.

Nietzsche's abandonment of theology to philology, during his scholarly age, affected him. This informed why he was very critical of Christianity. Consequently, he came up with the declaration that "God is dead." This means, for him, the death of the suprasensory world in general. It is a statement of crises of values. Thus, Nietzsche's postulation of the superman was an attempt to deal with this crisis of value, which he calls nihilism. But this attempt failed because it ended abruptly. The superman ended up being an ideal postulation, which did not materialize existentially. Similarly, Conway (2014) is of the view that "it may be fruitful to regard the enigmatic superman in terms of the possibilities that arise when decadence itself is treated as a potentially productive context for reconstituting the human soul" (cited in Fortich, 2010, p.80) This implies that although Nietzsche claims in Zarathustra that man is something that must be overcome, he never suggested that the post modern man -his superman- would consist of anything that does not in some ways exist in the present man. However, despite all these shortcomings, Nietzsche's philosophy undoubtedly remains a crucial factor in the history of the development of philosophical thought.

\section{References}

Bruno, Y. I. and Ojimba, C.A. (2018). Philosophy and education: The engines of national development. Journal of Philosophy, Culture and Religion,37-30-6.

Coplestone, F. (1963). A history of philosophy. Vol. 7. New York: Image Books Ltd.

Erikson, E.H. (2013). Identity: Youth and crisis. In religion and identity. Oppong, S. American International Journal of Contemporary Research, 3,10-16.

Fortich I. (2010). Nietzsche's ubermensch: The notion of a higher aristocracy of the future. Civilizar, 10(12), 75 80.

Gayon, J. 1. (2011). Nietzsche and Darwin. In Friedrich Nietzsche's superman, a child of Darwin. Creation Research Society Quarterly, 47, 205-211.

Heidegger, M. (1977). The question concerning technology and other essays. Trans. William Lovitt. New York: Harper and Row Publishers.

Jacob, O.D. and Ojimba, A.C. (2017). Friedrich Nietzsche's will to power, globalization and democratic values in Africa. Ndunode: University of Calabar Journal of Humanities, 12(1), 76-91.

Nietzsche, F. (1966). Beyond good and evil. Trans. Walter Kaufmann. New York: Vintage Books.

Nietzsche, F. (2006). Thus spoke Zarathustra. Trans. Adrian Del Caro and Robert Pippin. New York: Cambridge 
University Press.

Nietzsche, F. (2005). Twilight of the idle. Ed. Aeron Ridley and Judith Norman. New York: Cambridge University Press.

Nietzsche, F. (1967). The will to power. Trans. Walter Kaufmann and R. J. Hollingdale. New York: Vintage Books.

Nietzsche, F. (2004). The antichrist: A curse on christianity. Trans. Thomas Wayne. New York: Roubiczek, P. (1966). Existentialism for and against. London: Cambridge University Press.

Nietzsche, F. (1999). The birth of tragedy. Ed. Raymond Geuss and Ronald Speirs. New York: Cambridge University Press.

Nietzsche, F. (1989). On the genealogy of morals. Trans. Walter Kaufmann. New York: Vintage Books.

Ojimba, C.A. and Bruno, Y. I. (2015). On the problem of language in African philosophy. Contemporary Journal of Art and Science, 1(2), 104-113.

Ojimba, C.A. (2013). Ethnicity and national integration in Nigeria: The historical role of colonialism. Contemporary Journal of Educational Research, 5(1), 15-33.

Strangroom, J. and Garvey, J. (2006). The great philosophers. Royston: Eagle Editions Limited.

Algora publishing.

Sahakian, W. (1996). The history of philosophy from the earliest times to the present. New York: Barnes and Noble Books.

Stumpf, S and Fiester, J. (1996). Philosophy: History and problems. New York: McGraw-Hill Book Company.

Anthony Chimamkpam Ojimba is lecturer in the Department of Philosophy, University of Nigeria, Nsukka, Nigeria. He is the Nigerian South East Coordinator, Researchers International Network (RIN). He is also a member, Nigeria Philosophical Association (NPA). He holds a Ph.D in Metaphysics from the University of Nigeria, Nsukka.

Bruno Yammeluan Ikuli (M'14) is a Philosophy lecturer in Federal University Otuoke, Bayelsa State, Nigeria. $\mathrm{He}$ is the Coordinator, General Education Studies (GES). He became a Member, Researchers International Network in 2014. That same year (2014), he became a Member, Nigeria Philosophical Association (NPA). He holds a Ph.D. in Social and Political Philosophy from the University of Nigeria, Nsukka. 